\title{
Assessment of GNSS-based height data of multiple ships for measuring and forecasting great tsunamis
}

Daisuke Inazu ${ }^{1 *}$, Takuji Waseda ${ }^{1,2}$, Toshiyuki Hibiya ${ }^{1,3}$ and Yusaku Ohta ${ }^{4}$

\begin{abstract}
Ship height positioning by the Global Navigation Satellite System (GNSS) was investigated for measuring and forecasting great tsunamis. We first examined GNSS height-positioning data of a navigating vessel. If we use the kinematic precise point positioning (PPP) method, tsunamis greater than $10^{-1} \mathrm{~m}$ will be detected by ship height positioning. Based on Automatic Identification System (AIS) data, we found that tens of cargo ships and tankers are usually identified to navigate over the Nankai Trough, southwest Japan. We assumed that a future Nankai Trough great earthquake tsunami will be observed by the kinematic PPP height positioning of an AIS-derived ship distribution, and examined the tsunami forecast capability of the offshore tsunami measurements based on the PPP-based ship height. A method to estimate the initial tsunami height distribution using offshore tsunami observations was used for forecasting. Tsunami forecast tests were carried out using simulated tsunami data by the PPP-based ship height of 92 cargo ships/ tankers, and by currently operating deep-sea pressure and Global Positioning System (GPS) buoy observations at 71 stations over the Nankai Trough. The forecast capability using the PPP-based height of the 92 ships was shown to be comparable to or better than that using the operating offshore observatories at the 71 stations. We suppose that, immediately after the occurrence of a great earthquake, stations receiving successive ship information (AlS data) along certain areas of the coast would fail to acquire ship data due to strong ground shaking, especially near the epicenter. Such a situation would significantly deteriorate the tsunami-forecast capability using ship data. On the other hand, operational real-time analysis of seismic/geodetic data would be carried out for estimating a tsunamigenic fault model. Incorporating the seismic/geodetic fault model estimation into the tsunami forecast above possibly compensates for the deteriorated forecast capability.
\end{abstract}

Keywords: Tsunami forecast, Ship height, Global navigation satellite system (GNSS), Precise point positioning (PPP), Automatic identification system (AIS)

\section{Background}

Great megathrust earthquakes with moment magnitude $\left(M_{\mathrm{w}}\right)$ greater than about 8.5 have generated great tsunamis that caused disastrous damages with significant wave height $\left(>10^{0} \mathrm{~m}\right)$ and inundation for near-field coastal communities during tens of minutes after the earthquake occurrence (Paris et al. 2010; Mori et al. 2011; Fujii and Satake 2013; Joint Editorial Committee for the Report on

\footnotetext{
*Correspondence: inazud@oa.u-tokyo.ac.jp

1 UTokyo Ocean Alliance, The University of Tokyo, 7-3-1 Hongo, Bunkyo, Tokyo 113-0033, Japan

Full list of author information is available at the end of the article
}

the Great East Japan Earthquake Disaster 2014). It is necessary to develop and operate practical tsunami warning/ forecast systems for coastal disaster mitigation (Bernard and Titov 2015).

Seismic wave monitoring systems enable us to rapidly estimate earthquake source (Okada et al. 2004; Hayes et al. 2009; Ekström et al. 2012). The simplest forecast method is to select a possible tsunami scenario from a precomputed database based on the estimated seismic magnitude with its hypocenter location (Tatehata 1997; Kamigaichi 2009; Lauterjung et al. 2010; Abe and Imamura 2010; Igarashi et al. 2015), requiring only minutes to obtain a forecast result after the earthquake occurrence. 
Tsunami calculation using the seismically estimated earthquake mechanism (i.e., moment tensor) probably provides more reliable estimation (Reymond et al. 2012; Gusman and Tanioka 2014). Such methods are incorporated into operational systems of the Pacific Tsunami Warning Center (PTWC) (Wang et al. 2012; PTWC/ITIC 2014), the French Polynesian Tsunami Warning Center (CPPT: Centre Polynésien de Prévention des Tsunamis) (Clément and Reymond 2015; Jamelot and Reymond 2015), and the National Research Institute for Earth Science and Disaster Resilience (NIED), Japan (Inazu et al. 2016). These systems require $10-20$ min to obtain a reliable seismic moment tensor solution of a tsunamigenic earthquake, and additional time to calculate the tsunami.

In general, the rapid estimation of tsunami size using seismic observations alone becomes relatively difficult for greater earthquakes $\left(M_{\mathrm{w}}>8.0\right)$. This is because the source time function of greater earthquakes is relatively longer than that of smaller earthquakes, and thus source estimation of greater earthquakes requires longer-period seismic wave analysis (up to a couple of hundreds of seconds) than smaller ones (Katsumata et al. 2013). In addition, greater earthquakes may involve tsunami earthquakes (Satake 1994; Dutykh et al. 2012) and seafloor failures due to strong seafloor shaking which can generate additional tsunamis (Kawamura et al. 2014; Løvholt et al. 2015).

We prefer to use information that strongly reflects the tsunami rather than earthquake for robust and reliable tsunami forecasting.

Onshore Global Navigation Satellite System (GNSS) observations have detected coseismic land deformation due to great tsunamigenic earthquakes. Real-time GNSS data with high sampling (e.g., $1 \mathrm{~Hz}$ ) possibly enable us to rapidly estimate the earthquake size and its expansion (i.e., coseismic fault model) that can more directly relate to the generated tsunami than the conventional point source estimation based on seismic wave analysis alone (Blewitt et al. 2006; Ohta et al. 2012; Wright et al. 2012; Colombelli et al. 2013). For the case of near-coast great tsunamigenic earthquakes, these GNSS analyses possibly work well to obtain a reliable fault model within about $10 \mathrm{~min}$. Using the estimated fault model with the latest supercomputing systems can facilitate real-time tsunami forecasting with suitable inundation (Oishi et al. 2015; Baba et al. 2016).

Deep-sea pressure and Global Positioning System (GPS or GNSS) sea-surface buoy observations which have been proven established technologies (Kawai et al. 2013; Rabinovich and Eblé 2015) can directly measure offshore tsunamis. Tsunami forecast systems using deep-sea pressure and/or GPS buoy observations have been developed and are operated by the National Oceanic and Atmospheric
Administration (NOAA) (Tang et al. 2009, 2012) and the Japan Meteorological Agency (JMA) (Tsushima et al. 2009, 2011, 2012). These forecast systems are suitably reliable but require substantially longer time, because it typically takes tens of minutes for a tsunami to reach to the nearest offshore stations (Tsushima et al. 2011; Tang et al. 2012; Wei et al. 2013). Several studies have suggested the combined use of seismic/geodetic observations as well as offshore tsunami observations will facilitate rapid and reliable forecasting (Melgar and Bock 2013, 2015; Tsushima et al. 2014; Wei et al. 2014).

On the other hand, we may also detect offshore tsunami signals using other measurements. One possible method is ship-borne GNSS positioning. The GNSS-based ship height positioning for navigation purposes should reflect the sea-surface height at the ship location, which is in principle the same as the GPS buoy observation. Offshore tsunami of $0.1 \mathrm{~m}$ due to the 2010 Maule, Chile, earthquake was successfully detected by GNSS-based height of a research vessel (Foster et al. 2012). A fine spatial-scale geoidal variation was possibly captured by GNSS height of a navigating commercial ship (Roggenbuck et al. 2014). Routine recording of GNSS height of a navigating ferryboat may be useful for monitoring of seasurface height spatiotemporal variations that reflect the Tsushima Warm Current (Ichikawa et al. 2013). These reports show that GNSS-based ship height observations have become useful for geophysical applications.

The ship's GNSS information during navigation has been increasingly aggregated as Automatic Identification System (AIS) data. Due to the International Maritime Organization (IMO) regulation, ships exceeding 300 gross tonnage engaged on international voyages, cargo ships exceeding 500 gross tonnage not engaged on international voyages, and all passenger ships must send their AIS information including their location during navigation (IMO 2002). The AIS information sent via very-highfrequency (VHF) radio signals from ships is received successively by terrestrial AIS stations within a range of about $100 \mathrm{~km}$ from the stations, and by low Earth orbit (LEO) satellites when the ships are within footprint of the satellites which is a couple of thousands of kilometers (Bekkadal 2009; Earles et al. 2010; Eriksen et al. 2010). The number of such recognized ships was 60,000 over the global ocean in 2009 (Herbert-Burns et al. 2009), and is increasing year by year with the increase in seaborne trade (Barki and Rogers 2015).

The location information of current AIS data include only latitude and longitude (excluding height), and mostly involves relatively low-precision (meter-order) accuracy due to the use of GNSS single positioning with code pseudorange observable, because the AIS data are mainly used for maritime traffic safety and trade statistics. On 
the other hand, higher-precision positioning has become required for safe berthing of large vessels (e.g., liquefied natural gas (LNG) tankers) (Oda et al. 2009). The precise point positioning (PPP) method (Zumberge et al. 1997; Kouba and Héroux 2001) has been widely used for onshore geophysical positioning (Ohta et al. 2006; Yamamoto et al. 2013; Li et al. 2013a, b), and recently for offshore buoy positioning (Terada et al. 2015; Takahashi et al. 2015). PPP facilitates centimeter-accuracy positioning using carrier phase observable with precise satellite orbits and clock data as external information. PPP requires no reference station or baseline, which is different from other precise positioning methods such as the real-time kinematics (RTK) or differential GPS methods. This is a great advantage in offshore positioning because large amounts of telemetry of raw GNSS data at a reference station are not practical under poor offshore Internet connectivity. We expect in the near future that AIS data will possibly include successive time series of ship positioning including height derived from such high-precision GNSS.

In the present study, GNSS height data of a navigating ship are first investigated for the tsunami detection. We carry out tsunami forecast tests for the great tsunami scenario at the Nankai Trough, southwest Japan, using offshore tsunami pseudo observations. The pseudo observation data at the Nankai Trough region are generated based on currently operating offshore tsunami observatories, and GNSS height data of multiple ships derived from AIS data. We discuss future application of GNSS ship height data and tsunami forecast system.

\section{GNSS-based height record of a navigating ship}

We investigate the quality of GNSS height-positioning records of a navigating ship. The ship was the Dai-San Kaiyo Maru which was used for seafloor geodesy by Tohoku University, Japan, from 24 February to 3 March in 2014 (Fig. 1a) (Kido et al. 2015). The kinematic PPP method (Ohta et al. 2006; Yamamoto et al. 2013) was adopted for the high-precision position determination. In the GNSS data processing, we used RTKLIB v.2.4.2 (RTKLIB, An open source program package for GNSS positioning, http://www.rtklib.com). For comparison between different positioning methods, we also used typical single-positioning method (hereafter SINGLE) and differential GPS method (hereafter DGPS) using code pseudorange data.

Ship height records for every $1 \mathrm{~s}$ were estimated as the ellipsoidal height for all the positioning solutions (Fig. 1b). Moving average during a 1-min time window was carried out for removing wind-wave effects in order to easily find long-wave signals (e.g., tsunami and tide). Possible geophysical corrections were carried out on the height records. Static geoidal height which depends on location $\left(\sim 10^{1} \mathrm{~m}\right)$ was primarily removed using the EGM 2008 model (Pavlis et al. 2012). Ocean tides $\left(<10^{0} \mathrm{~m}\right)$ were removed using the NAO.99Jb model (Matsumoto et al. 2000).

We assess the noise level of the ship height time series from the SINGLE, DGPS, and PPP methods (Fig. 1d). While the noise levels are meters for the SINGLE and DGPS methods, but are effectively $<10^{-1} \mathrm{~m}$ for the PPP method at a frequency of $0.01-0.1 \mathrm{cpm}$ that is mostly involved in great tsunamis $\left(M_{\mathrm{w}}>8.5\right)$ (Rabinovich and Eblé 2015). Great megathrust earthquakes $\left(M_{\mathrm{w}}>8.5\right)$ have involved tsunami amplitude greater than $10^{-1} \mathrm{~m}$ in deep seas near the epicenters (Inazu and Saito 2013). We expect such large amplitude tsunamis will be detected by ship height positioning using PPP.

Although ship attitudes generally change due to ship motion (Reinking 2010; Reinking et al. 2012), we could find no remarkable noises related to the ship movement (i.e., velocity/acceleration) in the PPP ship height record (Fig. 1b, c). We consider that detailed assessment of the attitude change effects on the ship positioning is beyond the scope of the present study, and so do not discuss this.

\section{Nankai Trough great earthquake}

We assume that PPP ship height data of multiple ships are available in real time. In the present study, we examine usefulness of the PPP ship height for great tsunami forecasting. The Nankai Trough great earthquake tsunami is used as an example for the evaluation of the tsunami forecast capability. The Tokai-Tonankai-Nankai great earthquake tsunami scenario with $M_{\mathrm{w}} 8.7$ (Central Disaster Prevention Council 2003) is considered for the tsunami forecast test (Fig. 2).

There are currently operating offshore tsunami observatories in the Nankai Trough region (Fig. 3a). Deep-sea pressure gauges are operating at 63 stations, and GPS sea-surface buoys are operating at eight stations (Tsushima and Ohta 2014). The pressure gauges are connected to land via seafloor cables, which are operated by the Japan Agency for Marine-Earth Science and Technology (JAMSTEC) (Momma et al. 1997; Kasaya et al. 2009; Kaneda et al. 2015), JMA (Isozaki et al. 1980; Fujisawa et al. 1986; Saito et al. 2007), and NIED (Eguchi et al. 1998). The GPS buoys are operated by the Port and Airport Research Institute (PARI) (Kawai et al. 2013).

Based on AIS data, we find that there are usually a number of ships navigating over the Nankai Trough. There were 64 cargo ships and 28 tankers navigating offshore (sea depth $>300 \mathrm{~m}$ ) in the Nankai Trough region on 1 January 2015 (Fig. 3b). The locations of these ships were successively monitored by terrestrial AIS data-receiving stations within the AIS VHF transmission range (i.e., $<\sim 100 \mathrm{~km}$ ). In addition to real-time data retrieval of the deep-sea pressure and GPS buoy observations, we 


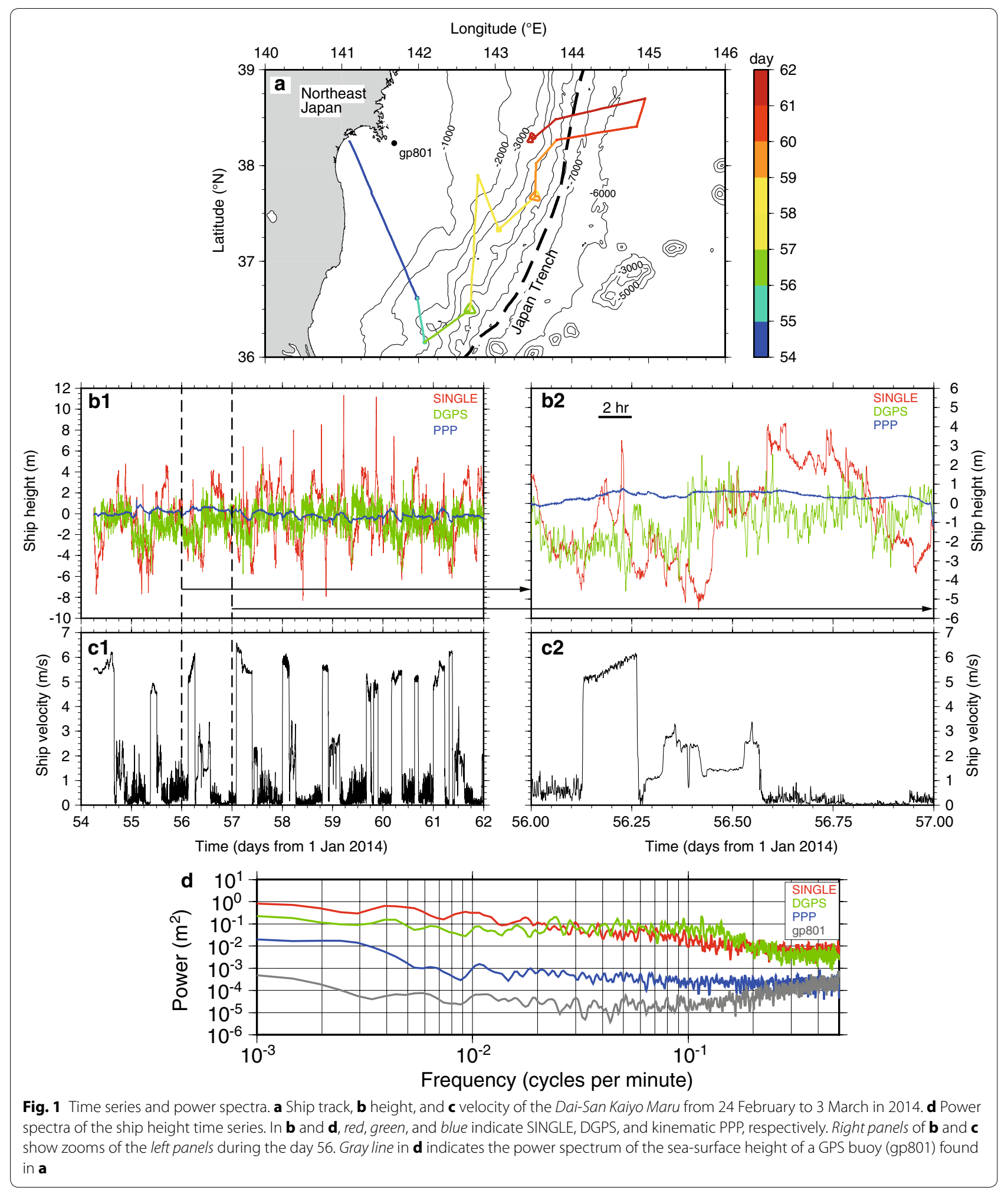




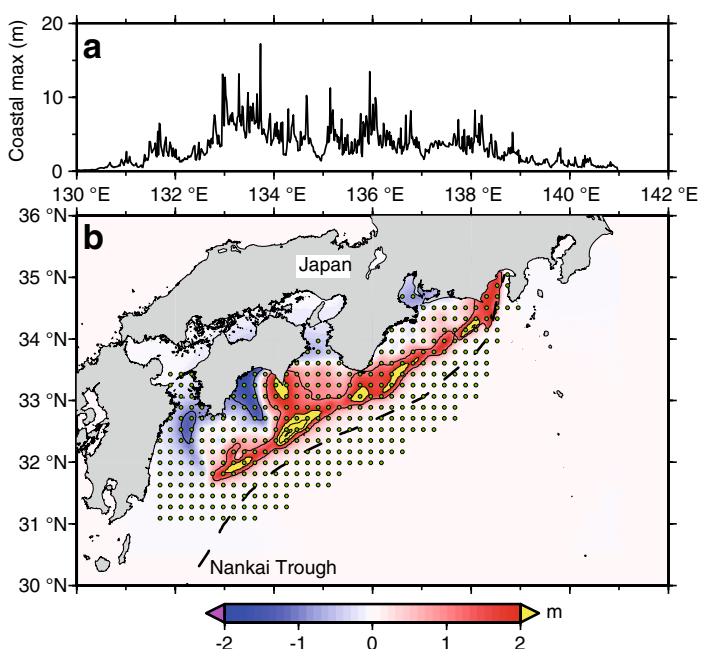

Fig. 2 Tsunami scenario due to the great Nankai Trough earthquake $\left(M_{w}\right.$ 8.7). a Maximum tsunami height at the coast calculated from the tsunami scenario. $\mathbf{b}$ Initial tsunami height of the tsunami scenario with 376 unit sources (green circles) used for the forecast test. Red and blue indicate elevation and subsidence, respectively. Dashed curve indicates the Nankai Trough

assume that PPP height data of these ships are available in real time via terrestrial AIS stations.

\section{Tsunami forecast tests}

\section{Procedure}

The procedure of the tsunami forecast is described. The tsunami forecast method is based on the tsunami Forecasting based on Inversion for initial sea-Surface Height (tFISH) (Tsushima et al. 2009, 2011, 2012). The following procedure was introduced by Inazu and Saito (2014). Based on a linear inversion, we use offshore tsunami observation data to estimate the initial tsunami height as the tsunami source for the forecasting. The observation here is pseudo observation explained later in this subsection. The initial tsunami height is configured by a linear superposition of the unit sources. The unit sources are assigned in the Nankai Trough region with a $20-\mathrm{km}$ interval (Fig. 2). The total number of the unit sources is 376 . Each unit source is given by a Gaussian-shaped function:

$$
\begin{gathered}
\eta_{j}(\phi, \theta)=\exp \left[-\left(\phi-\phi_{j} / R_{\phi}\right)^{2}-\left(\theta-\theta_{j} / R_{\theta}\right)^{2}\right] \\
(j=1, \ldots, 376)
\end{gathered}
$$

where $\phi$ and $\theta$ are longitude and latitude, respectively. $R_{\phi}$ and $R_{\theta}$ are both set to correspond to $12.5 \mathrm{~km}$. Green's functions (or basis functions) at the assumed observation points are calculated by tsunami simulations initial conditions of which are the respective unit sources. The tsunami simulation is based on a linear long-wave model. The weights on the unit sources are the model parameters that are optimized based on a well-known linear equation:

$$
\left(\begin{array}{l}
\mathbf{A} \\
\lambda \mathbf{I}
\end{array}\right) \mathbf{m}=\left(\begin{array}{l}
\mathbf{d} \\
\mathbf{0}
\end{array}\right)
$$

where $\mathbf{A}$ is a matrix produced by the Green's functions; $\mathbf{m}$ is the model parameter vector of the unit source weights of dimension 376; and $\mathbf{d}$ is a vector filled by the pseudo observation data used for the forecasting. In short, we assume that the pseudo observation is represented by a linear superposition of the Green's functions from the unit sources, and estimate the weights of the unit sources $(\mathbf{m})$ by this linear inversion. The tsunami heights
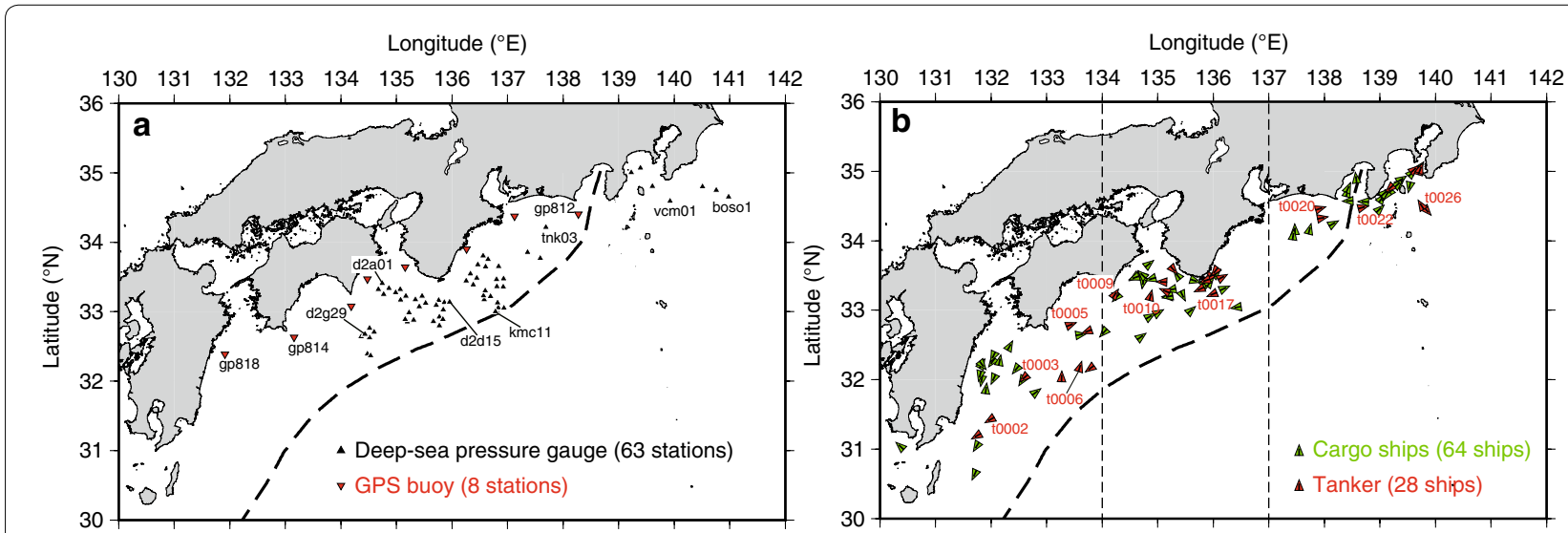

Fig. 3 Offshore tsunami observations. a Currently operating offshore tsunami observatories using deep-sea pressure gauges and GPS buoys. b Navigating ships in the offshore region (sea depth $>300 \mathrm{~m}$ ) recognized by terrestrial AlS receivers on 1 January 2015 
anywhere are also synthesized or forecasted from the estimated $\mathbf{m}$. In addition, I is a unit matrix, and an operation of damping using a scalar factor $\lambda$ is incorporated to penalize the $L_{2}$ norm of $\mathbf{m}$ in order to avoid overfitting of the model (Menke 1989; Bishop 2006).

Pseudo observation data (d) are made for the tsunami forecast test. The tsunami signals at the observation points are calculated by the linear long-wave simulation of the Tokai-Tonankai-Nankai earthquake tsunami scenario (Fig. 2). Random noises are added to the tsunami signals, which are used as the pseudo observations. The random noises are generated by inverse Fourier transform with phase randomization of the power spectra of Fig. 1d. The noises based on PPP are added to the tsunami time series, which is used as the ship height pseudo observation. Since the ship velocities are $10^{\circ} \mathrm{m} / \mathrm{s}$ (Fig. 1c), ship movements during the tsunami passing over the offshore ships ( $30 \mathrm{~min}$ ) are expected to be $<10 \mathrm{~km}$, which is not considered in the present study. The pseudo observation data of the ships are thus generated at fixed points (Fig. 3b). GPS buoy noises (Fig. 1d) are added to the GPS buoy observation. No noise is added to the deep-sea pressure observation which is sensitive to subcentimeter tsunamis (Filloux 1982; Hino et al. 2001; Inazu and Saito 2014).

The data interval for the forecast in the present study is taken as $3-10$ or 3-20 min after the tsunami generation, as shown later. The first 3-min data are omitted because the sea surface and bottom are expected to be significantly affected by elastic wave effects immediately after the earthquake (Nosov and Kolesov 2007; Saito 2013). In the tsunami forecast tests, $\lambda$ is empirically fixed, respectively, for using the data from the operating offshore observatories, and for using the PPP ship height data (Inazu and Saito 2014).

\section{Deep-sea pressure and GPS buoy}

The tsunami forecast using the pseudo observations of both deep-sea pressure and GPS buoy (Fig. 3a) is carried out, and is used as reference of the forecast capability. The forecast results using the 3-10-min and 3-20-min data are shown in Fig. 4. Although the forecast result using the 3-10-min data provides good estimation in terms of the maximum coastal tsunami height along the coast, the estimated source shows false subsidence region in the south of the Nankai Trough. The correlation coefficients between the tsunami scenario (Fig. 2) and the forecast are 0.88 for the maximum coastal height, and 0.63 for the source. When the 3-20-min data are used, the forecast result is improved in terms of the maximum coastal height and the source. The correlation coefficients become 0.94 and 0.77 for the maximum coastal height and the source, respectively. The time interval of 3-10 min used for the forecast is probably insufficient for reliable forecast using the deep-sea pressure data in the epicentral region because the tsunami and the permanent seafloor vertical deformation are hardly distinguished during this short-term observation (Tsushima et al. 2012).

\section{PPP ship height}

The tsunami forecast is carried out using the pseudo observations of 92 ships (Fig. 3b). The tsunami signals at the offshore ships are greater than tens of centimeters, showing a high ratio of the tsunami signal to the PPP noise (Fig. 5). Then, the forecast results using the PPP ship height data are relatively comparable to or better than those using the deep-sea pressure and GPS buoy observations (Figs. 4, 5). The ship height primarily reflects the sea-surface height or the tsunami height. This is an advantage over the deep-sea pressure in the epicentral region just after the tsunami generation. The observation distribution of the ships (Fig. 3b) is broader and more uniform than that of the deep-sea pressure and GPS buoy observations (Fig. 3a). Broad and uniform observation distribution would be also favorable for good forecasting.

Here, the PPP noise was added to the tsunami simulation data used for the tsunami forecast test. When we instead used noises of SINGLE and DGPS, it was found to be difficult to obtain reliable tsunami forecasts, since ratios of the tsunami signals to these noises were relatively low (Additional file 1: Figure S1). However, a possible source of the great tsunami would be identified using a number of such low-precision-positioning data by a careful analysis for post-tsunami evaluations. It is still important to explore the use of currently available data.

We can suppose that terrestrial AIS stations near the epicenter may fail to acquire successive ship information just after the great earthquake occurrence due to its strong ground shaking (Oshima et al. 2011). Such a situation will significantly deteriorate the tsunami forecast capability proposed above. Here we assume that ships are not totally recognized in an offshore region from $134^{\circ}$ to $137^{\circ} \mathrm{E}$. The number of the available ships for this case becomes 55 (38 cargo ships and 17 tankers) (Fig. 3b). The forecast result using the 55 ship data significantly underestimates the coastal tsunami height in this region (Fig. 6).

On the other hand, operational real-time seismic and/ or geodetic analysis will be carried out independent of the tsunami data analysis. A moment tensor or a certain fault model would be suitably obtained by routine analysis systems of seismic and/or geodetic data inversions (Okada et al. 2004; Kawamoto et al. 2015). We assume to successfully obtain a rectangular fault model solution 

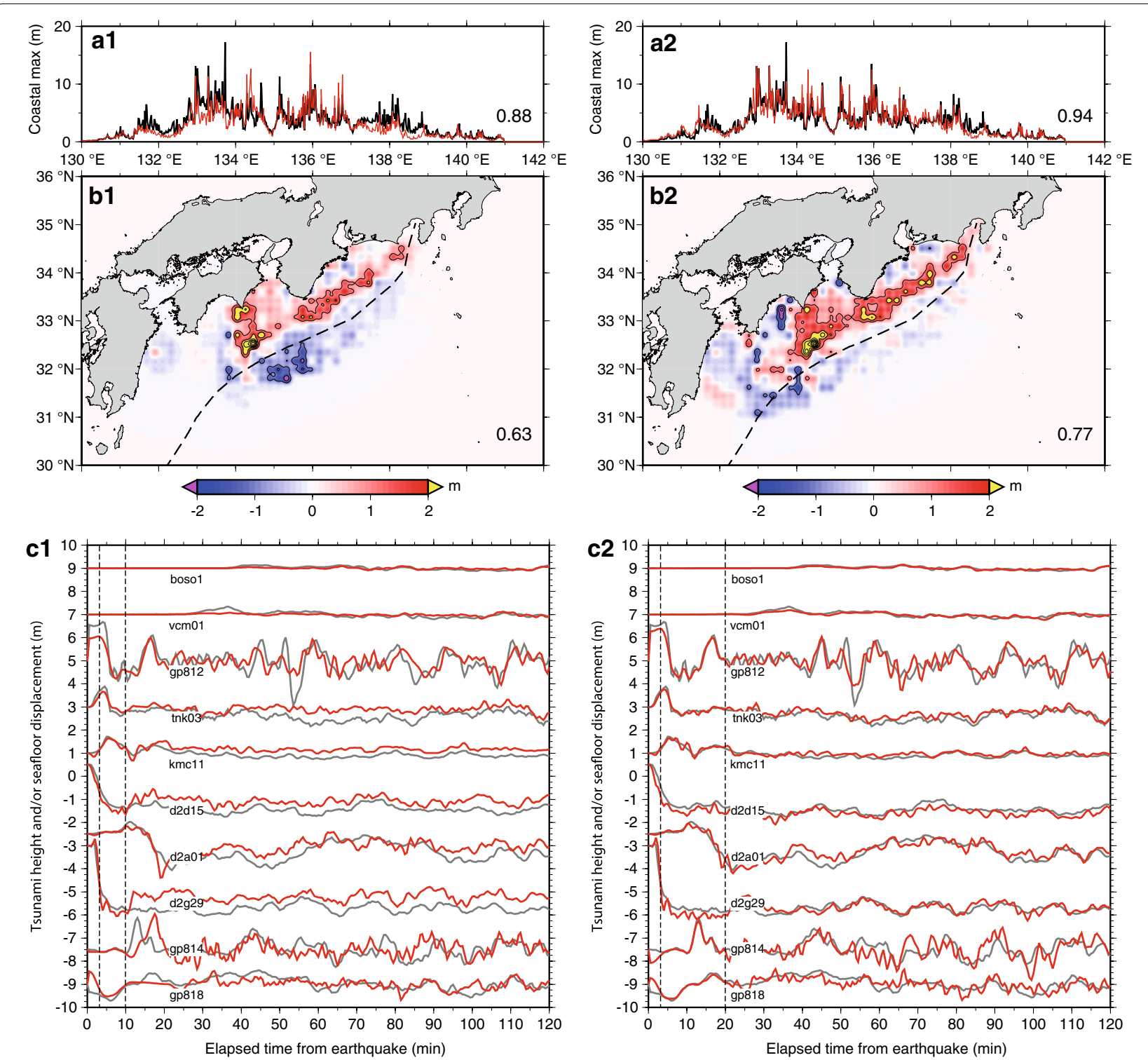

Fig. 4 Forecast results. a Estimated maximum tsunami height (red) with that of the tsunami scenario of Fig. 2 (black). b Estimated tsunami source. cTsunami time series at selected stations (Fig. 3a) of the estimation (red) and the pseudo observation (gray). Left and right panels show the results using 3-10-min and 3-20-min pseudo observation data, respectively, from the operating offshore observatories (Fig. 3a) for the case of $\lambda=0.2$. Correlation coefficients between the estimation and the tsunami scenario of Fig. 2 are shown in the right-bottom sides in $\mathbf{a}$ and $\mathbf{b}$

$\left(M_{\mathrm{w}} 8.4\right)$ in about 5-15 min after the earthquake occurrence (Fig. 6c). This fault model solution is incorporated as a first guess into the tsunami forecast. The basic concept of this procedure was proposed by Tsushima et al. (2014). The forecast with the fault model shows a notably improved result (Fig. 6). It is worth noting that combined use of multivariate data (i.e., seismic, geodetic, tsunami, and so on) possibly compensates for the weakness of single variable data analysis during great events with complex disasters.

\section{Discussion for practical use of ship height data}

The tsunami forecast of Fig. 5 is an example based on a ship distribution (Fig. 3b). However, the ship distribution will not always be spatially uniform. In order to practically carry out the inversion/forecast, we must prepare a dense Green's function database, and select and/or make Green's functions according to the ship distribution, possibly considering the ship moving after the earthquake occurrence. Optimal damping parameter $(\lambda)$ probably depends on data amount used (number of ships) and 

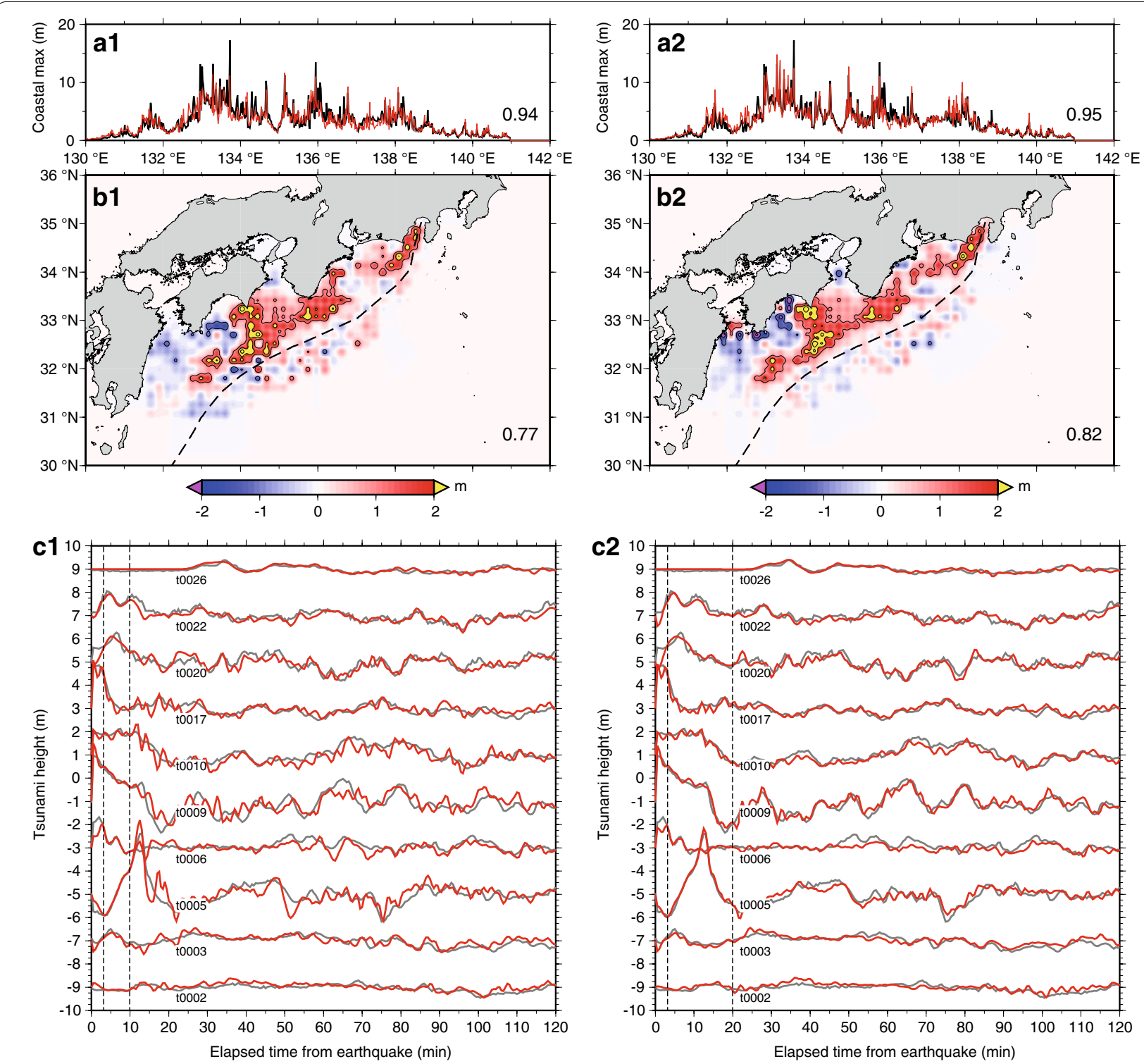

Fig. 5 Forecast results. These are same as Fig. 4 but using the pseudo observation data from the GNSS ship height (Fig. 3b) with the PPP noises (Fig. 1d) for the case of $\lambda=0.05$

ratios of tsunami signals to background noises. It is necessary to beforehand prepare optimal parameters that depend on ship distributions used. When the tsunami occurs, we will choose an optimal $\lambda$ that is compatible with the ship distribution at the time, and carry out the forecasting.

As mentioned above, great earthquakes may prevent us from acquiring local ship data close to the epicenters, which will sometimes make it difficult to reliably carry out inversion-based forecasts. It is important to prepare multiple alternatives so that the forecast system becomes robust. For example, local coastal communities may prepare a simplified forecast method such as that based on the Green's law (Baba et al. 2004, 2014; Hayashi 2010) using their navigating ships.

Real-time and stable GNSS data retrieval is essential so that we efficiently carry out the proposed tsunami forecasting. We should incorporate practical methods to at least resolve problems of stable phase ambiguity resolutions and cycle slips (data gaps) for operational real-time PPP analyses (Ge et al. 2008; Li et al. 2013c, 2014; Guo and Zhang 2014). As mentioned above, external information of precise satellite orbits and clock data is necessary for the real-time kinematic PPP analysis. In the offshore 

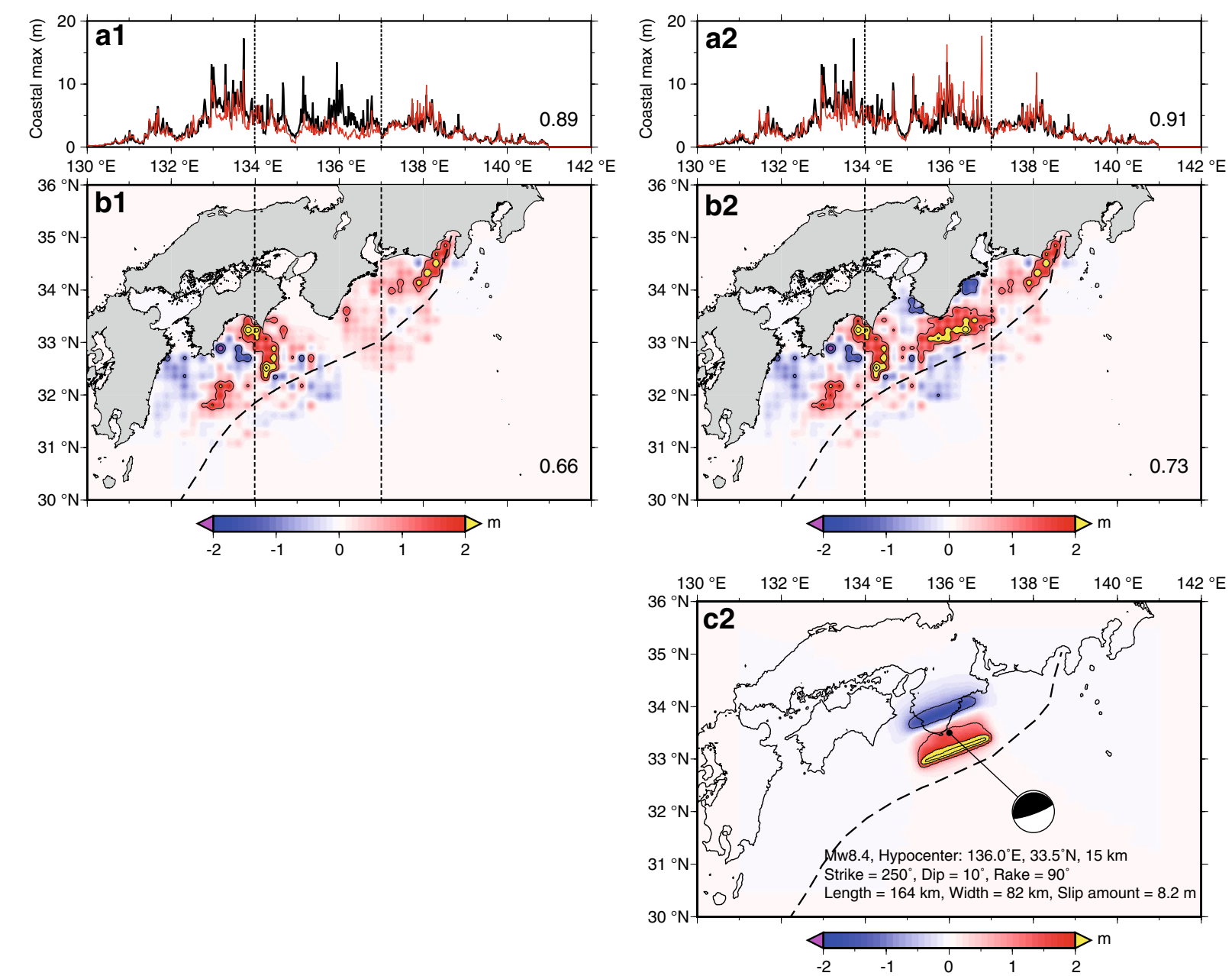

Fig. 6 Forecast results and a rectangular fault model. a Estimated maximum tsunami height (red) with that of the tsunami scenario of Fig. 2 (black). b Estimated tsunami source. c Surface deformation based on a rectangular fault model assumed to be obtained from operational real-time seismic/ geodetic data analysis. The forecast results are obtained using 3-20-min pseudo observation data from the PPP ship height $(\lambda=0.05)$ but excluding those at a region from $134^{\circ}$ to $137^{\circ} \mathrm{E}$ (Fig. $3 \mathrm{~b}$ ). Left and right panels show the forecast result using the 55 ship data, and that using not only the 55 ship data but incorporating the fault model of $\mathbf{c}$, respectively. Correlation coefficients between the estimation and the tsunami scenario of Fig. 2 are shown in the right-bottom sides in $\mathbf{a}$ and $\mathbf{b}$

region, it is not easy to acquire this external information due to poor Internet connectivity while it is easy for the onshore use. However, commercial services (e.g., StarFire $^{\mathrm{TM}}$ ) have provided the external information for PPP via geostationary satellites (Sharpe et al. 2000; Dixon 2006). The Japan Aerospace Exploration Agency (JAXA) has also developed a real-time PPP correction message named as Multi-GNSS Advanced Demonstration tool for Orbit and Clock Analysis (MADOCA), and began experimental transmission of the MADOCA signal via the Japanese Quasi Zenith Satellite System (QZSS) (Suzuki et al. 2014). These tools will be increasingly useful for the precise position determination in the offshore region. When the real-time PPP analysis in the offshore region becomes practical and robust, a data center will be necessary in order to receive successive AIS data and make the data available for real-time forecasting.

The present study considered AIS data received by terrestrial stations. Meanwhile LEO satellites can also receive AIS data of far offshore ships within the satellite footprint. If the number of LEO satellites increases, successive ship data during whole navigation over quasi-global ocean may become available. Although GNSS ship positioning used in the current AIS is generally low precision, using highprecision positioning will give us incentives of geophysical applications as well as of safe berthing (Oda et al. 2009). If the number of the users of high-precision GNSS positioning increases as a result of decreasing prices, such a 
crowdsourced dataset will have wide potentials including geophysical applications (Foster et al. 2012; Ichikawa et al. 2013; Roggenbuck et al. 2014).

\section{Summary and remarks}

We investigated GNSS-based ship height-positioning data for offshore tsunami detection and its use for forecasting. Tsunamis greater than $10^{-1} \mathrm{~m}$ will be detected if kinematic PPP method is used for ship height positioning. We assumed that kinematic PPP is installed for the offshore ships derived from AIS data, and examined the capabilities of the tsunami forecast of a great tsunami scenario $\left(M_{\mathrm{w}} 8.7\right)$ (Central Disaster Prevention Council 2003) using the PPP ship heights as well as those recorded using the currently operating offshore tsunami observatories in the Nankai Trough region. The forecast accuracy using the PPP ship heights would be comparable to or better than that using the operating offshore observatories. Terrestrial AIS stations may fail to receive successive ship data due to strong ground shaking during a great earthquake, which will deteriorate the forecast capability. We showed that the lack of the tsunami (ship) data would be compensated for by employing combined analyses of both the tsunami data analysis and the operational seismic/geodetic coseismic source estimation.

The present study can be viewed as an ocean version of the crowdsourced earthquake warning by US researchers (Minson et al. 2015; Kong et al. 2016). Japan has the world's densest earthquake and tsunami observatories in both land and ocean (Okada et al. 2004; Kanazawa 2013; Kaneda et al. 2015). Rapid earthquake and tsunami warning and forecast systems are expected to work well for future great Nankai Trough and Japan Trench earthquakes and tsunamis (Tsushima and Ohta 2014). However, there are coastal countries and cities that cannot install such dense observatories especially in the deep seas due to economic, security, and geographic reasons. These countries and cities may consider the concept in the present study as a future tsunami warning and disaster mitigation system (NRC 2011).

In the present study, the GNSS-based ship height was investigated to measure offshore tsunamis. As one of other offshore measurements, satellite altimetry has been well known to detect significant tsunamis (Gower 2004; Hamlington et al. 2011; Song et al. 2012), and its nearreal-time use has been also investigated (Hamlington et al. 2012). GNSS-reflectometry using numerous GNSS satellites and LEO satellites may also be a promising technique for detecting offshore tsunamis over vast areas of ocean in a relatively short time interval (Stosius et al. 2010). Real-time use of these satellite measurements and applications will hopefully be examined in the future.

\section{Additional file}

Additional file 1: Figure S1. Forecast results. (a) Estimated maximum tsunami height (red) with that of the tsunami scenario of Fig. 2 (black). (b) Estimated tsunami source. (c) Tsunami time series at selected stations (Fig. 3b) of the estimation (red) and the pseudo observation (gray). These are the results using 3-20-min pseudo observation data from GNSS ship height (Fig. 3b). Left and right panels show the results using SINGLE $(\lambda=1.0)$ and DGPS $(\lambda=0.5)$ noises (Fig. 1d), respectively. Correlation coefficients between the estimation and the tsunami scenario of Fig. 2 are shown in the right-bottom sides in (a) and (b).

\section{Authors' contributions}

DI designed and carried out the study, and wrote the paper. TW provided detailed information on the AIS and ship data. YO acquired and processed the GNSS data of the Dai-San Kaiyo Maru. TW, TH, and YO contributed extensively to the scientific discussion. All authors read and approved the final manuscript.

\section{Author details}

${ }^{1}$ UTokyo Ocean Alliance, The University of Tokyo, 7-3-1 Hongo, Bunkyo, Tokyo 113-0033, Japan. ${ }^{2}$ Graduate School of Frontier Sciences, The University of Tokyo, Tokyo, Japan. ${ }^{3}$ Graduate School of Science, The University of Tokyo, Tokyo, Japan. ${ }^{4}$ Research Center for Prediction of Earthquakes and Volcanic Eruptions, Graduate School of Science, Tohoku University, Sendai, Japan.

\section{Acknowledgements}

The authors greatly thank Prof. Motoyuki Kido at the Tohoku University for providing the raw GNSS data of the Dai-San Kaiyo Maru. The AIS data used in the present study were compiled by IHS Maritime \& Trade. This study was supported by the Nippon Foundation. The authors also thank the Editor-in-Chief, Kenji Satake, and the two anonymous reviewers for their careful reading and useful comments.

\section{Competing interests}

The authors declare that they have no competing interests.

Received: 1 May 2016 Accepted: 1 August 2016

Published online: 17 August 2016

\section{References}

Abe I, Imamura F (2010) Study on the evaluation of tsunami inundation in real time with database and its accuracy. J Jpn Soc Civil Eng B2(66):261-265. doi:10.2208/kaigan.66.261 (in Japanese with English abstract)

Baba T, Hirata K, Kaneda Y (2004) Tsunami magnitude determined from data of ocean-bottom pressure gauges around Japan. Geophys Res Lett 31:L08303. doi:10.1029/2003GL019397

Baba T, Takahashi N, Kaneda Y (2014) Near-field tsunami amplification factors in the Kii peninsula, Japan for dense oceanfloor network for earthquakes and tsunamis (DONET). Mar Geophys Res 35:319-325. doi:10.1007/s11001-013-9189-1

Baba T, Ando K, Matsuoka D, Hyodo M, Hori T, Takahashi N, Obayashi R, Imato Y, Kitamura D, Uehara H, Kato T, Saka R (2016) Large-scale, high-speed tsunami prediction for the Great Nankai Trough Earthquake on the K computer. Int J High Perform Comput Appl 30:71-84. doi:10.1177/1094342015584090

Barki D, Rogers J (2015) Review of maritime transport 2015, United Nations conference on trade and development. United Nations publication, Geneva

Bekkadal F (2009) Novel maritime communications technologies. In: Weintrit A (ed) Marine navigation and safety of sea transportation. CRC Press, Boca Raton, pp 307-312. doi:10.1201/9780203869345.ch55

Bernard E, Titov V (2015) Evolution of tsunami warning systems and products. Phil Trans R Soc A 373:20140371. doi:10.1098/rsta.2014.0371

Bishop CM (2006) Pattern recognition and machine learning. Springer-Verlag, New York 
Blewitt G, Kreemer C, Hammond WC, Plag H-P, Stein S, Okal E (2006) Rapid determination of earthquake magnitude using GPS for tsunami warning systems. Geophys Res Lett 33:L11309. doi:10.1029/2006GL026145

Central Disaster Prevention Council (2003) Report associated with Tonankai and Nankai earthquakes. http://www.bousai.go.jp/kaigirep/chuobou/9/ pdf/zuhyou_2-2.pdf. Accessed 28 June 2016 (in Japanese)

Clément J, Reymond D (2015) New tsunami forecast tools for the French Polynesia tsunami warning system Part l: moment tensor, slowness and seismic source inversion. Pure Appl Geophys 172:791-804. doi:10.1007/ s00024-014-0888-6

Colombelli S, Allen RM, Zollo A (2013) Application of real-time GPS to earthquake early warning in subduction and strike-slip environments. J Geophys Res Solid Earth 118:3448-3461. doi:10.1002/jgrb.50242

Dixon K (2006) StarFire ${ }^{\mathrm{TM}}$ : A global SBAS for subdecimeter precise point positioning. In: Proc 19th international technical meeting of the satellite division of the institute of navigation (ION GNSS 2006), Fort Worth, pp 2286-2296

Dutykh D, Mitsotakis D, Chubarov LB, Shokin YI (2012) On the contribution of the horizontal sea-bed displacements into the tsunami generation process. Ocean Model 56:43-56. doi:10.1016/j. ocemod.2012.07.002

Earles M, CANEUS Shared Small Satellites CSSP Workshop Committee (2010) International space-based AIS and data extraction backbone, high level requirements. CANEUS International, Montreal

Eguchi T, Fujinawa Y, Fujita E, Iwasaki S, Watabe I, Fujiwara H (1998) A real-time observation network of ocean-bottom-seismometers deployed at the Sagami trough subduction zone, central Japan. Mar Geophys Res 20:73-94. doi:10.1023/A:1004334021329

Ekström G, Nettles M, Dziewoński AM (2012) The global CMT project 2004-2010: centroid-moment tensors for 13,017 earthquakes. Phys Earth Planet Inter 200-201:1-9. doi:10.1016/j.pepi.2012.04.002

Eriksen T, Skauen AN, Narheim B, Helleren $\varnothing$, Olsen $\varnothing$, Olsen RB (2010) Tracking ship traffic with space-based AIS: experience gained in first months of operations. In: 2010 Int Waterside Secur Conf (WSS). doi:10.1109/ WSSC.2010.5730241

Filloux JH (1982) Tsunami recorded on the open ocean floor. Geophys Res Lett 9:25-28. doi:1 10.1029/GL009i001 p00025

Foster JH, Brooks BA, Wang D, Carter GS, Merrifield MA (2012) Improving tsunami warning using commercial ships. Geophys Res Lett 39:L09603. doi:10.1029/2012GL051367

Fujii Y, Satake K (2013) Slip distribution and seismic moment of the 2010 and 1960 Chilean earthquakes inferred from tsunami waveforms and coastal geodetic data. Pure Appl Geophys 170:1493-1509. doi:10.1007/ s00024-012-0524-2

Fujisawa I, Tateyama S, Funazaki J (1986) Permanent ocean bottom earthquake and tsunami observation system off the Boso Peninsula. Weather Serv Bull 53:127-166 (in Japanese)

Ge M, Gendt G, Rothacher M, Shi C, Liu J (2008) Resolution of GPS carrierphase ambiguities in precise point positioning (PPP) with daily observations. J Geod 82:389-399. doi:10.1007/s00190-007-0187-4

Gower J (2004) The 26 December 2004 tsunami measured by satellite altimetry. Int J Remote Sens 28(13-14):2897-2913. doi:10.1080/01431160601094484

Guo F, Zhang X (2014) Real-time clock jump compensation for precise point positioning. GPS Solut 18:41-50. doi:10.1007/s10291-012-0307-3

Gusman AR, Tanioka Y (2014) W Phase inversion and tsunami inundation modeling for tsunami early warning: case study for the 2011 Tohoku event. Pure Appl Geophys 171:1409-1422. doi:10.1007/s00024-013-0680-z

Hamlington BD, Leben RR, Godin OA, Legeais JF, Gica E, Titov VV (2011) Detection of the 2010 Chilean tsunami using satellite altimetry. Nat Hazards Earth Syst Sci 11:2391-2406. doi:10.5194/nhess-11-2391-2011

Hamlington BD, Leben RR, Godin OA, Gica E, Titov VV, Haines BJ, Desai SD (2012) Could satellite altimetry have improved early detection and warning of the 2011 Tohoku tsunami? Geophys Res Lett 39:L15605. doi: 10.1029/2012GL052386

Hayashi Y (2010) Empirical relationship of tsunami height between offshore and coastal stations. Earth Planets Space 62:269-275. doi:10.5047/ eps.2009.11.006

Hayes GP, Rivera L, Kanamori H (2009) Source inversion of the W-Phase: realtime implementation and extension to low magnitudes. Seismol Res Lett 80:817-822. doi:10.1785/gssrl.80.5.817
Herbert-Burns R, Bateman S, Lehr P (2009) Lloyd's MIU handbook of maritime security. CRC Press, Boca Raton

Hino R, Tanioka Y, Kanazawa T, Sakai S, Nishino M, Suyehiro K (2001) Microtsunami from a local interplate earthquake detected by cabled offshore tsunami observation in northeastern Japan. Geophys Res Lett 28:3533-3536. doi:10.1029/2001GL013297

Ichikawa K, Morimoto A, Fukudome K, Yoon J-H, Yoshikawa Y (2013) Coastal sea surface dynamic height monitoring by GPS mounted on a ferry boat. In: Ouwehand L (ed) Proc 20 years of progress in radar Altimetry, Venice, Italy. doi:10.5270/esa.sp-710.altimetry2012

Igarashi Y, Ueno T, Nakata K, Hernandez-Grennan VC, Cruz-Salcedo JL, Narag IC, Bautista BC, Koizumi T (2015) Building a tsunami simulation database for the tsunami warning system in the Philippines. J Disaster Res 10:51-58. doi:10.20965/jdr.2015.p0051

Inazu D, Saito T (2013) Simulation of distant tsunami propagation with a radial loading deformation effect. Earth Planets Space 65:835-842. doi:10.5047/eps.2013.03.010

Inazu D, Saito T (2014) Two subevents across the Japan Trench during the 7 December 2012 off Tohoku earthquake (Mw 7.3) inferred from offshore tsunami records. J Geophys Res Solid Earth 119:5800-5813. doi:10.1002/ 2013JB010892

Inazu D, Pulido N, Fukuyama E, Saito T, Senda J, Kumagai H (2016) Near-field tsunami forecast system based on near real-time seismic moment tensor estimation in the regions of Indonesia, the Philippines, and Chile. Earth Planets Space 68:73. doi:10.1186/s40623-016-0445-x

International Maritime Organization (IMO) (2002) Guidelines for the onboard operational use of shipborne Automatic Identification System (AIS). Resolution A.917(22), London

Isozaki I, Den N, linuma T, Matsumoto H, Takahashi M, Tsukakoshi T (1980) Deep sea pressure observation and its application to pelagic tide analysis. Pap Meteorol Geophys 31:87-96. doi:10.2467/mripapers.31.87

Jamelot A, Reymond D (2015) New tsunami forecast tools for the French Polynesia tsunami warning system Part II: numerical modelling and tsunami height estimation. Pure Appl Geophys 172:805-819. doi:10.1007/ s00024-014-0997-2

Joint Editorial Committee for the Report on the Great East Japan Earthquake Disaster (2014) Report on the Great East Japan Earthquake Disaster, fundamental aspects 2, The tsunami and its Impact. Maruzen Co Ltd, Tokyo, Japan (in Japanese)

Kamigaichi O (2009) Tsunami forecasting and warning. In: Meyers RA (ed) Encyclopedia of complexity and systems science. Springer, New York, pp 9592-9618. doi:10.1007/978-0-387-30440-3_568

Kanazawa T (2013) Japan trench earthquake and tsunami monitoring network of cable-linked 150 ocean bottom observatories and its impact to earth disaster science. In: Proc Intl Symp Underwater Technology (UT), 2013. doi:10.1109/UT.2013.6519911

Kaneda Y, Kawaguchi K, Araki E, Matsumoto H, Nakamura T, Kamiya S, Ariyoshi K, Hori T, Baba T, Takahashi N (2015) Development and application of an advanced ocean floor network system for megathrust earthquakes and tsunamis. In: Favali P, Beranzoli L, De Santis A (eds) Seafloor observatories. Springer, Berlin, pp 643-662. doi:10.1007/978-3-642-11374-1_25

Kasaya T, Mitsuzawa K, Goto TN, Iwase R, Sayanagi K, Araki E, Asakawa K, Mikada H, Watanabe T, Takahashi I, Nagao T (2009) Trial of multidisciplinary observation at an expandable sub-marine cabled station "off-Hatsushima Island observatory" in Sagami Bay, Japan. Sensors 9:9241-9254. doi:10.3390/s91109241

Katsumata A, Ueno H, Aoki S, Yoshida Y, Barrientos S (2013) Rapid magnitude determination from peak amplitudes at local stations. Earth Planets Space 65:843-853. doi:10.5047/eps.2013.03.006

Kawai H, Satoh M, Kawaguchi K, Seki K (2013) Characteristics of the 2011 Tohoku tsunami waveform acquired around Japan by NOWPHAS equipment. Coast Eng J 55:1350008. doi:10.1142/S0578563413500083

Kawamoto S, Miyagawa K, Yahagi T, Todoriki M, Nishimura T, Ohta Y, Hino R, Miura S (2015) Development and assessment of real-time fault model estimation routines in the GEONET real-time processing system. Int Assoc Geod Symp. doi:10.1007/1345_2015_49

Kawamura K, Laberg JS, Kanamatsu T (2014) Potential tsunamigenic submarine landslides in active margins. Mar Geol 356:44-49. doi:10.1016/j. margeo.2014.03.007

Kido M, Fujimoto H, Hino R, Ohta Y, Osada Y, linuma T, Azuma R, Wada I, Miura S, Suzuki S, Tomita F, Imano M (2015) Progress in the project for 
development of GPS/acoustic technique over the last 4 years. Int Assoc Geod Symp. doi:10.1007/1345_2015_127

Kong Q, Allen RM, Schreier L, Kwon Y-W (2016) MyShake: a smartphone seismic network for earthquake early warning and beyond. Sci Adv 2:e1501055. doi:10.1126/sciadv.1501055

Kouba J, Héroux P (2001) Precise point positioning using IGS orbit and clock products. GPS Solut 5:12-28. doi:10.1007/PL00012883

Lauterjung J, Münch U, Rudloff A (2010) The challenge of installing a tsunami early warning system in the vicinity of the Sunda Arc, Indonesia. Nat Hazards Earth Syst Sci 10:641-646. doi:10.5194/ nhess-10-641-2010

Li X, Ge M, Zhang X, Zhang Y, Guo B, Wang R, Klotz J, Wickert J (2013a) Realtime high-rate co-seismic displacement from ambiguity-fixed precise point positioning: application to earthquake early warning. Geophys Res Lett 40:295-300. doi:10.1002/grl.50138

Li X, Ge M, Zhang Y, Wang R, Xu P, Wickert J, Schuh H (2013b) New approach for earthquake/tsunami monitoring using dense GPS networks. Sci Rep 3:2682. doi:10.1038/srep02682

Li X, Ge M, Zhang H, Wickert J (2013c) A method for improving uncalibrated phase delay estimation and ambiguity-fixing in real-time precise point positioning. J Geod 87:405-416. doi:10.1007/s00190-013-0611-x

Li X, Guo B, Lu C, Ge M, Wickert J, Schuh H (2014) Real-time GNSS seismology using a single receiver. Geophys J Int 198:72-89. doi:10.1093/gji/ ggu113

Løvholt F, Pedersen G, Harbitz CB, Glimsdal S, Kim J (2015) On the characteristics of landslide tsunamis. Phil Trans R Soc A 373:20140376. doi:10.1098/ rsta.2014.0376

Matsumoto K, Takanezawa T, Ooe M (2000) Ocean tide models developed by assimilating TOPEX/POSEIDON altimeter data into hydrodynamical model: a global model and a regional model around Japan. J Oceanogr 56:567-581. doi:10.1023/A:1011157212596

Melgar D, Bock Y (2013) Near-field tsunami models with rapid earthquake source inversions from land- and ocean-based observations: the potential for forecast and warning. J Geophys Res Solid Earth 118:5939-5955. doi:10.1002/2013JB010506

Melgar D, Bock Y (2015) Kinematic earthquake source inversion and tsunami runup prediction with regional geophysical data. J Geophys Res Solid Earth 120:3324-3349. doi:10.1002/2014JB011832

Menke W (1989) Geophysical data analysis: discrete inverse theory. Academic Press, San Diego

Minson SE, Brooks BA, Glennie CL, Murray JR, Langbein JO, Owen SE, Heaton TH, lannucci RA, Hauser DL (2015) Crowdsourced earthquake early warning. Sci Adv 1:e1500036. doi:10.1126/sciadv.1500036

Momma H, Fujisawa N, Kawaguchi K, Iwase R, Suzuki S, Kinoshita H (1997) Monitoring system for submarine earthquakes and deep sea environment. In: Proc oceans 1997 mar technol soc IEEE techno-ocean, pp 1453-1459. doi:10.1109/OCEANS.1997.624211

Mori N, Takahashi T, The 2011 Tohoku Earthquake Tsunami Joint Survey Group (2012) Nationwide post event survey and analysis of the 2011 Tohoku earthquake tsunami. Coast Eng J 54:1250001. doi:10.1142/ S0578563412500015

National Research Council (NRC) (2011) Tsunami warning and preparedness: an assessment of the US tsunami program and the nation's preparedness efforts. The National Academies Press, Washington, DC. doi:10.17226/12628

Nosov M, Kolesov V (2007) Elastic oscillations of water column in the 2003 Tokachi-oki tsunami source: in situ measurements and 3-D numerical modelling. Nat Hazards Earth Syst Sci 7:243-249. doi:10.5194/ nhess-7-243-2007

Oda H, Okuyama E, Kawamori Y (2009) New berthing support system using high accuracy differential GPS, application to safety navigation management. J Jpn Inst Mar Eng 44:64-69. doi:10.5988/jime.44.64

Ohta Y, Sagiya T, Kimata F (2006) Assessment of the long-term stability of the PPP kinematic GPS. J Geod Soc Jpn 52:309-318. doi:10.11366/ sokuchi1954.52.309 (in Japanese with English abstract)

Ohta Y, Kobayashi T, Tsushima H, Miura S, Hino R, Takasu T, Fujimoto H, linuma T, Tachibana K, Demachi T, Sato T, Ohzono M, Umino N (2012) Quasi real-time fault model estimation for near-field tsunami forecasting based on RTK-GPS analysis: application to the 2011 Tohoku-Oki earthquake (Mw9.0). J Geophys Res Solid Earth 117:B02311. doi:10.1029/20 11JB008750
Oishi Y, Imamura F, Sugawara D (2015) Near-field tsunami inundation forecast using the parallel TUNAMI-N2 model: application to the 2011 TohokuOki earthquake combined with source inversions. Geophys Res Lett 42:1083-1091. doi:10.1002/2014GL062577

Okada Y, Kasahara K, Hori S, Obara K, Sekiguchi S, Fujiwara H, Yamamoto A (2004) Recent progress of seismic observation networks in JapanHi-net, F-net, K-NET and KiK-net-. Earth Planets Space 56:15-28. doi:10.1186/BF03353076

Oshima K, Miura Y, Kageyama I, Furuya Y, Yahagi T, Maruyama K (2011) Emergency repair and restoration of damaged GPS and tide stations after the 2011 off the pacific coast of Tohoku earthquake. J Geos Info Auth Jpn 122:113-125 (in Japanese)

Pacific Tsunami Warning Center/International Tsunami Information Center (PTWC/ITIC) (2014) Users guide for the Pacific Tsunami Warning Center enhanced products for the Pacific Tsunami Warning System, Revised edn. IOC Technical Series 105, UNESCO/IOC, Paris, France

Paris R, Fournier J, Poizot E, Etienne S, Morin J, Lavigne F, Wassmer P (2010) Boulder and fine sediment transport and deposition by the 2004 tsunami in Lhok Nga (western Banda Aceh, Sumatra, Indonesia): a coupled offshore-onshore model. Mar Geol 268:43-54. doi:10.1016/j. margeo.2009.10.011

Pavlis NK, Holmes SA, Kenyon SC, Factor JK (2012) The development and evaluation of the earth gravitational model 2008 (EGM2008). J Geophys Res Solid Earth 117:B04406. doi:10.1029/2011JB008916

Rabinovich AB, Eblé M (2015) Deep-ocean measurements of tsunami waves. Pure Appl Geophys 172:3281-3312. doi:10.1007/s00024-015-1058-1

Reinking J (2010) Marine geodesy. In: Xu G (ed) Sciences of geodesy-I, advances and future directions. Springer-Verlag, Berlin, pp 275-299. doi:10.1007/978-3-642-11741-1_8

Reinking J, Härting A, Bastos L (2012) Determination of sea surface height from moving ships with dynamic corrections. J Geod Sci 2:172-187. doi:10.2478/v10156-011-0038-3

Reymond D, Okal EA, Hébert H, Bourdet M (2012) Rapid forecast of tsunami wave heights from a database of pre-computed simulations, and application during the 2011 Tohoku tsunami in French Polynesia. Geophys Res Lett 39:L11603. doi:10.1029/2012GL051640

Roggenbuck O, Reinking J, Härting A (2014) Oceanwide precise determination of sea surface height from in situ measurements on cargo ships. Mar Geod 37:77-96. doi:10.1080/01490419.2013.868385

Saito T (2013) Dynamic tsunami generation due to sea-bottom deformation: analytical representation based on the linear potential theory. Earth Planets Space 65:1411-1423. doi:10.5047/eps.2013.07.004

Saito S, Moriwaki K, Yamada Y (2007) JMA's new ocean bottom seismographs (OBS) using marine cable installed at the sea of Enshu to the sea of Kumano. In: Proc underwater technology and workshop on scientific use of submarine cables and related technologies (UT/SSC) 2007, pp 639-646. doi:10.1109/UT.2007.370828

Satake K (1994) Mechanism of the 1992 Nicaragua tsunami earthquake. Geophys Res Lett 21:2519-2522. doi:10.1029/94GL02338

Sharpe T, Hatch R, Nelson F (2000) John Deere's StarFire system: WADGPS for precision agriculture. In: Proc 13th international technical meeting of the satellite division of the institute of navigation (ION GPS 2000), Salt Lake City, pp 2269-2277

Song YT, Fukumori I, Shum CK, Yi Y (2012) Merging tsunamis of the 2011 Tohoku-Oki earthquake detected over the open ocean. Geophys Res Lett 39:L05606. doi:10.1029/2011GL050767

Stosius R, Zeyerle B, Helm A, Hoechner A, Wickert J (2010) Simulation of space-borne tsunami detection using GNSS-reflectometry applied to tsunamis in the Indian Ocean. Nat Hazards Earth Syst Sci 10:1359-1372. doi:10.5194/nhess-10-1359-2010

Suzuki T, Kubo N, Takasu T (2014) Evaluation of precise point positioning using MADOCA-LEX via Quasi-Zenith satellite system. In: Proc 2014 international technical meeting of the institute of navigation, San Diego, pp $460-470$

Takahashi N, Ishihara Y, Fukuda T, Ochi H, Tahara J, Mori T, Deguchi M, Kido M, Ohta Y, Hino R, Mutoh K, Hashimoto G, Motohashi O, Kaneda Y (2015) Buoy platform development for observation of tsunami and crustal deformation. Int Assoc Geod Symp. doi:10.1007/1345_2015_114

Tang L, Titov V, Chamberlin CD (2009) Development, testing, and applications of site-specific tsunami inundation models for real-time forecasting. J Geophys Res Ocean 114:C12025. doi:10.1029/2009JC005476 
Tang L, Titov W, Bernard EN, Wei Y, Chamberlin CD, Newman JC, Mofjeld HO, Arcas D, Eble MC, Moore C, Uslu B, Pells C, Spillane M, Wright L, Gica E (2012) Direct energy estimation of the 2011 Japan tsunami using deepocean pressure measurements. J Geophys Res Oceans 117:C08008. doi: 10.1029/2011JC007635

Tatehata H (1997) The new tsunami warning system of the Japan Meteorological Agency. In: Hebenstreit G (ed) Perspectives on tsunami hazard reduction. Springer, Berlin, pp 175-188. doi:10.1007/978-94-015-8859-1_12

Terada Y, Kato T, Nagai T, Koshimura S, Imada N, Sakaue H, Tadokoro K (2015) Recent developments of GPS tsunami meter for a far offshore observations. Int Assoc Geod Symp. doi:10.1007/1345_2015_151

Tsushima H, Ohta Y (2014) Review on near-field tsunami forecasting from offshore tsunami data and onshore GNSS data for tsunami early warning. J Disaster Res 9:339-357. doi:10.20965/jdr.2014.p0339

Tsushima H, Hino R, Fujimoto H, Tanioka Y, Imamura F (2009) Near-field tsunami forecasting from cabled ocean bottom pressure data. J Geophys Res Solid Earth 114:B06309. doi:10.1029/2008JB005988

Tsushima H, Hirata K, Hayashi Y, Tanioka Y, Kimura K, Sakai S, Shinohara M, Kanazawa T, Hino R, Maeda K (2011) Near-field tsunami forecasting using offshore tsunami data from the 2011 off the pacific coast of Tohoku earthquake. Earth Planets Space 63:821-826. doi:10.5047/ eps.2011.06.052

Tsushima H, Hino R, Tanioka Y, Imamura F, Fujimoto H (2012) Tsunami waveform inversion incorporating permanent seafloor deformation and its application to tsunami forecasting. J Geophys Res Solid Earth 117:B03311 doi:10.1029/2011 JB008877

Tsushima H, Hino R, Ohta Y, linuma T, Miura S (2014) tFISH/RAPiD: rapid improvement of near-field tsunami forecasting based on offshore tsunami data by incorporating onshore GNSS data. Geophys Res Lett 41:3390-3397. doi:10.1002/2014GL059863
Wang D, Becker NC, Walsh D, Fryer GJ, Weinstein SA, McCreery CS, Sardiña V, Hsu V, Hirshorn BF, Hayes GP, Duputel Z, Rivera L, Kanamori H, Koyanagi KK, Shiro B (2012) Real-time forecasting of the April 11, 2012 Sumatra tsunami. Geophys Res Lett 39:L19601. doi:10.1029/2012GL053081

Wei Y, Chamberlin C, Titov WV, Tang L, Bernard EN (2013) Modeling of the 2011 Japan tsunami: lessons for near-field forecast. Pure Appl Geophys 170:1309-1331. doi:10.1007/s00024-012-0519-z

Wei Y, Newman AV, Hayes GP, Titov VV, Tang L (2014) Tsunami forecast by joint inversion of real-time tsunami waveforms and seismic or GPS data: application to the Tohoku 2011 tsunami. Pure Appl Geophys 171:3281-3305. doi:10.1007/s00024-014-0777-z

Wright TJ, Houlié N, Hildyard M, Iwabuchi T (2012) Real-time, reliable magnitudes for large earthquakes from $1 \mathrm{~Hz}$ GPS precise point positioning: the 2011 Tohoku-Oki (Japan) earthquake. Geophys Res Lett 39:L12302. doi:10.1029/2012GL051894

Yamamoto J, Osada Y, Ohta Y, Hirahara S, Demachi T, Nakayama T, Tachibana K, Sato T, Kido M, Fujimoto H, Hino R, Miura S, Uchida M (2013) Real time GPS processing utilizing satellite communications-toward more reliable real-time crustal deformation monitoring under a situation of ground communication failure. J Geod Soc Jpn 59:133-145. doi:10.11366/sokuchi.59.133 (in Japanese with English abstract)

Zumberge JF, Heflin MB, Jefferson DC, Watkins MM, Webb FH (1997) Precise point positioning for the efficient and robust analysis of GPS data from large networks. J Geophys Res Solid Earth 102:5005-5017. doi:10.1029/96JB03860

\section{Submit your manuscript to a SpringerOpen ${ }^{\circ}$ journal and benefit from:}

- Convenient online submission

- Rigorous peer review

- Immediate publication on acceptance

- Open access: articles freely available online

- High visibility within the field

- Retaining the copyright to your article 